\title{
Encephalocele presented in late third trimester: a case report
}

\author{
Hemant G. Deshpande ${ }^{1}$, Chandrakant S. Madkar ${ }^{1}$, Sumit Jethani ${ }^{2}$, \\ Kajal Parikh ${ }^{1}$, Karuna Ratwani ${ }^{1}$ *
}

\author{
${ }^{1}$ Department of Obstetrics and Gynaecology, Dr DY Patil Medical College, Pune, Maharashtra, India \\ ${ }^{2}$ Department of Community Medicine, Dr DY Patil Medical College, Pune, Maharashtra, India
}

Received: 28 March 2014

Accepted: 14 April 2014

\author{
*Correspondence: \\ Dr. Karuna Ratwani, \\ E-mail: drkaruna@hotmail.com
}

(C) 2014 Deshpande HG et al. This is an open-access article distributed under the terms of the Creative Commons Attribution Non-Commercial License, which permits unrestricted non-commercial use, distribution, and reproduction in any medium, provided the original work is properly cited.

\begin{abstract}
In present era, most of the NTDs are diagnosed at quite early gestation, thanks to advancement in imaging technology. So it is rare to see a case of NTD in late gestational age. Encephalocele is still rare type of NTD, when we come across such a case in late gestational period associated with another risk factor (Previous LSCS), it can really present a challenge for management. We had to face such a case requiring skillful management. A 23 year, G2 P1 L1 with previous LSCS was referred to our institution for severe anemia. USG showed 37 weeks single, live fetus with absence of cranial vault\& irregular compressed cystic structure attached to vault attached in occipital region. Previous USG done at 12 weeks showed no abnormality, while USG at 27 weeks showed Acrania. Ideal management of this patient could have been done if this anomaly was diagnosed before 20 weeks where option of MTP was clearly available. Though with high resolution technical and instrument and with expert sonologist encephalocele can be diagnosed by 14 weeks.
\end{abstract}

Keywords: Congenital anomaly, Neural tube defects (NTD), Encephalocele

\section{INTRODUCTION}

The happiness \& romanticism of pregnancy suddenly turns to horror show when an anomalous child is born, more so if it is CNS defect, e.g. encephalocele as most of them are associated with severe disability and mental retardation

Encephalocele comes into a group of neural tube defects of congenital malformation of CNS and adjacent structures related to defective neural tube closure generally occurring between 18-29 days of gestational age. Ectodermal \& Mesodermal malformation may occur involving skull \& vertebrae as a result of defective neural tube closure. ${ }^{1}$ Hypothesis for deficiency includes failure of surface ectoderm to separate from neuroectoderm in early embryonic development.
Encephalocele refers to such defects where brain protrudes from gap in skull. ${ }^{2}$ It can also present alone or in association with other CNS anomaly. Its prevalence is estimated to be $0.8-4 / 10000$ live births. ${ }^{3}$ It occurs in 5$20 \%$ of all craniospinal malformation and abortion before 20 weeks and still birth is common sequelae.

Birth defects registry of India states prevalence of 2-3 / 100 live births have some congenital anomaly, amongst that NTD constitutes 2.5/1000 live births consisting mainly anencephaly \& spina bifida. Encephalocele is rare. Encephalocele is classified according to site of herniation \& named accordingly, like sincipital (Nasofrontal, Naso-orbital), parietal, occipital basal etc. It occurs at rate of $1 / 5000$ live births worldwide with demographic variations. They are also typed according to contents of herniation like meningocele, encephalocele, meningo-encephalocele, hydroencephalomeningocele. 
The exact etiology is not known, but malnutrition, genetic predisposition, infection, radiation are postulated in occurrence of it. Some specific factors like Folic acid deficiency ${ }^{4} \&$ maternal hyperthermia ${ }^{5}$ in early gestational age have been proved by some studies. It is usually diagnosed by ultrasound after 10 weeks because skull ossification begins at 10 weeks. ${ }^{6,7} \mathrm{CT} \&$ MRI can give detailed information. Some syndromes are associated with it like, Dandy-Walker, ${ }^{8}$ Walker-Walburg, ${ }^{9}$ Chiari malformation, Meckel-Gruber syndrome. ${ }^{10}$ Chromosomal anomaly is found in about $40 \%$ of cases.

Being CNS malformation, it requires management by highly equipped \& superspecialised centers which are lacking in India, so the prognosis is gloomy \& poor because occipital encephalocele is life threatening condition \& overall outcome depends on site \& size of lesion and associated other anomaly. Postoperative complication rate is very high $\&$ survivors are physically $\&$ intellectually disabled. ${ }^{11}$

\section{CASE REPORT}

A 23 year, G2 P1 L1 with previous LSCS was referred to our institution for severe anemia. USG showed 37 weeks single, live fetus with absence of cranial vault\& irregular compressed cystic structure attached to vault attached in occipital region. Previous USG done at 12 weeks showed no abnormality, while USG at 27 weeks showed Acrania.

\section{Obstetric history}

Married since 4 years with $1^{\text {st }}$ LSCS female child for fetal distress with postnatal diagnosis of tetralogy of fallot. Family history is not significant.

General examination showed significant pallor, abdominal examination showed, full term, relaxed uterus with cephalic presentation, FHS were 142/min, No scar tenderness.

Per vaginal examination showed, Uneffaced Cervix with closed os.

\section{Investigations}

$\mathrm{Hb}=7 \mathrm{gm} \%$, B +ve blood group, rest ANC profile was within normal limits. She was given 3 pints of blood transfusion over 5 days. Patient \& relatives were counselled for trial of vaginal delivery \& prognosis of fetus.

She was induced with cerviprime gel and had vaginal delivery of still born female child of $2.6 \mathrm{~kg}$. Baby was examined by pediatrician, there finding was large, tense \& cystic mass of $18 \times 12 \times 10 \mathrm{~cm}$ in the occipital region. Occipital bone was completely absent \& parietal bone showed partial absence. Head circumference was $13 \mathrm{~cm}$. There were no other significant findings \& diagnosis of large occipital encephalocele was made. As baby was still born it was not possible to rule out other associated anomaly.

Both husband \& wife were advised genetic study because $1^{\text {st }}$ child also had major congenital anomaly.

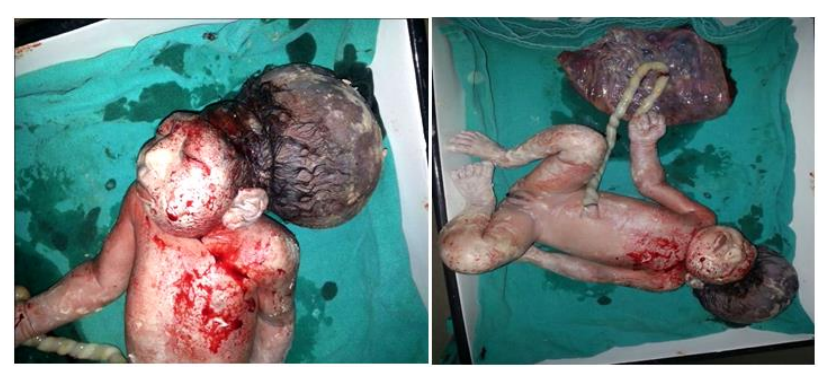

Figure 1: Shows large posterior encephalocele.

\section{DISCUSSION}

Ideal management of this patient could have been done if this anomaly was diagnosed before 20 weeks where option of MTP was clearly available. Though with high resolution technical and instrument and with expert sonologist encephalocele can be diagnosed by 14 weeks. In developed countries like though our facilities are at par in comparison with them, In India it should be definitely diagnosed up to 18 weeks where option of MTP is easily available. ${ }^{12}$ It is difficult to diagnose in the 1 st trimester because skull ossification begins at 10 weeks, but with advanced technology USG machines \& expert sonologists, it can be definitely diagnosed before 20 weeks so MTP can be done. But in this patient second USG was done at 27 weeks when legal MTP period was already crossed \& nothing could be done in spite of diagnosing major CNS anomaly. It was really surprising that $1^{\text {st }}$ child with Major Cardiac anomaly patient did not take this pregnancy seriously. This reflects the true tragedy of rural India \& social factors responsible for it like: false beliefs, poor socio-economic status, illiteracy, lack of proper healthcare facilities because of which the patient has to pay a heavy penalty. The child was still born which is a common observation in many studies, Verma et al. ${ }^{13}$ It was fortunate that she responded to induction \& had vaginal delivery, because if LSCS would have been required it would have added into morbidity \& suffering to the patient.

\section{Funding: No funding sources \\ Conflict of interest: None declared \\ Ethical approval: Not required}

\section{REFERENCES}

1. Joynt RJ. Chapter 55. In: Abe Bert Baker, Lowell H. Baker, eds. Clinical Neurology. 3rd ed. Philadelphia, PA: Lippincott; 1992: 31-41.

2. Rowland CA, Correa A, Cragan JD, Alverson CJ. Are encephaloceles neural tube defects. Pediatr. 2006 Sep;118(3):916-23. 
3. Radmanesh F, Nejat F, Monajemzadeh M. Teratoma within an encephalocele: common etiology or coincidence: case report. J Neurosurg. 2007 Sep;107(3 Suppl):263-5.

4. Laurence KM, James N, Miller MH, Tennant GB, Campbell H. Double-blind randomised controlled trial of folate treatment before conception to prevent recurrence of neural-tube defects. Br Med J (Clin Res Ed). 1981 May;282(6275):1509-11.

5. Edwards MJ. Hyperthermia as a teratogen: a review of experimental studies and their clinical significance. Teratog Carcinog Mutagen. 1986;6(6):563-82.

6. O. Rahilly R, Gardner E. The initial appearance of ossification in staged human embryos. Am $\mathbf{J}$ Anat. 1974;134:291-308.

7. Green JS, Hobbins JC. Abdominal ultrasound examination of the first trimester fetus. Am J Obstet Gynaecol. 1988;159:165-75.

8. Cakmak A, Zevek D, Cekin A, Karazebek H. DandyWalker syndrome together with occipital encephalocele. Minevva Paedatr J. 2008 Aug;60(4):465-8.
9. Martínez-Lage JF, García Santos JM, Poza M, Puche A, Casas C, Rodriguez Costa T. Neurosurgical management of Walker-Warburg syndrome. Childs Nerv Syst. 1995 Mar;11(3):145-53.

10. Wright C, Healism R, English C, Burn J. Meckel syndrome: what are the minimum diagnostic criteria. J Med Genet. 1994 Jun;31(6):482-5.

11. Ugras M, Karabekir HS, Kavak O, Sen TA, Alpay F. 577 occipital encephalocele: report of case series. Arch Dis Child. 2012;97:167-8.

12. Max Maizels, Bettinal Cuneo, Rudy Sabbagha. The 10 to 14 week scan. In: Max Maizels, Bettinal Cuneo, Rudy Sabbagha, eds. Fetal Anamolies: Ultasound Diagnosis And Post Natal Management. New York: Wiley Liss-A, John Willey and Sons Inc; 2004: 15-20.

13. Verma M, Chatwal J, Singh D. Congenital Malformations - A Retrospective study of 10000 cases. Indian J Pediatr. 1991;58:245-52.

DOI: $10.5455 / 2320-1770 . i j \operatorname{cog} 20140637$

Cite this article as: Deshpande HG, Madkar CS, Jethani S, Parikh K, Ratwani K. Encephalocele presented in late third trimester: a case report. Int J Reprod Contracept Obstet Gynecol 2014;3:460-2. 